\title{
THE INTERSUBJECTIVE TYPE OF RELIGIOSITY Theoretical Framework and Methodological Construction for Developing Human Sciences in a Progressive Muslim Perspective
}

\author{
M. Amin Abdullah \\ Sunan Kalijaga State Islamic University (UIN), Yogyakarta \\ email:aminabdullab53@gmail.com
}

\section{Abstract}

An everlasting and perpetual peace in the life of different religious adherents anywhere is the prime purpose of human beings. This article will discuss the methods and approaches of religious education in a contemporary multicultural society. Three approaches to the study of religion: dogmatic, critical, and ethical will be elaborated simultaneously. One cannot rely solely on one approach and neglects the two others without having their implications and consequences in the life of multi-religious society. In addition to the religious and Islamic studies perspectives, I will elaborate the issues based on philosophical concepts, i.e. subjective, objective, and intersubjective, as well. The subjective perspective is commonly based on 'ulum al-din, meanwbile the objective one is on social sciences. The combination between the two is called, in this paper, as an intersubjective pattern of religiosity. One of its distinctive features is its sensitivity towards, and its ability to accommodate, the presence of other communities whose rights are respected and guaranteed.

Kedamaian yang kekal dan abadi bagi semua pemeluk agama yang berbeda di berbagai aspek kebidupannya merupakan tujuan utama dari kemanusiaan. Artikel ini membahas beberapa metode dan pendekatan pendidikan agama pada masyarakat multikultural dewasa ini. Tiga pendekatan dalam pengkajian agama yang dogmatis, kritis dan etis akan dielaborasi secara simultan. Satu pendekatan tidak bisa berdiri sendiri dan menegasikan 
dua yang lain karena implikasinya dalam kehidupan masyarakat yang multireligius. Selain dalam perspektif keagamaan dan keislaman, artikel ini akan mengelaborasi persoalan di atas dengan pendekatan filosofis: subjektif, objektif, dan intersubjektif. Pendekatan subjektif umumnya didasarkan pada ulüm ad-dìn, sedangkan pendekatan objektif didasarkan pada ilmuilmu sosial. Perpaduan antara keduanya, dalam artikel ini, disebut dengan pola keagamaan yang intersubjektif. Salah satu kekhasan pola yang disebut terakbir ini adalah sensitifitasnya terhadap kehadiran kelompok lain dan kemampuannya mengakomodasi kelompok. lain tersebut sebagai pemegang hak-hak yang harus pula dijamin dan dihormati.]

Keywords: Islamic education, religious education, multicultural society, intersubjective religiosity

\section{A. Introduction}

The next important issue is the need to engage the Islamic scholars in a serious dialogue and convince them that scientists have much to say on topics that have been for too long remained a monopoly of the religious scholars and their discourse. While there is no doubt in people mind that buman knowledge evolves and grows, it is often understood that religions, especially Islam, are (is) absolute, immutable and transcendental principles, which are set in rigid frames of reference. But we know today that religions - and Islam in no exception - cannot afford to adopt a stationary attitude, lest they find themselves clashing with and overrun by modern knowledge, and religious principles appear more and more quaint and obsolete. ${ }^{1}$

Since the 1990s the world was shocked by Samuel Huntington's thesis mentioning the emergence of the clash of civilization that was the clash of civilizations of Islam and Christianity, Islam and Confucianism, Christianity and Confucianism, Islam and Judaism, of Hinduism and Islam or Christianity and so forth. Without wishing to justify the Huntington's thesis, in the reality of national and international relations, 20 years after the thesis was exposed, there had been some shocking world events such as like gunshots of the clash of civilizations, particularly the clashes between the supporters of 'dogmatic' secularism and 'dogmatic'

1 Nidhal Guessoum, Islam's Quantum Question: Reconciling Muslim Tradition and Modern Science (London: I.B. Tauris, 2010), pp. 343-4. 
religionism. The tragedy of September 11, 2001 and 2002 Bali bombings, and many others taking places in the areas of Afghanistan, Pakistan, Egypt, Syrian, South Sudan, Nigeria and the others constituted empirical evidence that the current era of human civilization cannot refute. There have even happened the clash-dogmatic zealots in one clump of religion itself, as it did in Sunni Muslims against the Ahmadiyya and Shiites and so on. Arab spring is still far from its termination. Its has a huge impact on the whole Muslim society as well as a world community. A socio-religious research and empirical study states that the world tends to be increasingly intolerant. Indeed, there is no positive correlation between any regulations, laws, government regulations, constitutions (Government Restriction Index) ${ }^{2}$ and the disharmony of social relations of internal as well as inter-religious denominations, groups and sects and even conflicts among those interest groups within religious communities themselves.(Social Hostility Index). Not only do such conflicts appear in the present era. In the cold war era there was also a clash between the 'dogmatic' secularism (United States and Western blocks) versus 'dogmatic' Secularism (Soviet Union and Eastern blocks). Although it is not referred to call them as blocks, even the history of middle century and its previous one were also often decorated by collisions in the forms of wars. Will a small planet inhabited by so many billions of humans suffer as predicted by Huntington? It could be true or not, depending on the attitudes and wisdoms of the world leaders, including the political elites and the elites of the world's major religions on the planet.

This paper is not going to elaborate the Huntington's thesis, but is trying to find a way out of the difficulties which most the human races perceived after the tragedy of 11 September 2001 and the Bali bombings a

2 Husni Thoyyar, "Dunia yang Semakin Tidak Toleran”, Kompas Jakarta, 22 Nov 2011); Tim PPIM, “Api dalam Sekam” Keberagamaan Muslim Gen-Z: Survei Nasional tentang Keberagaman di Sekolah dan Universitas di Indonesia (Jakarta: Pusat Pengkajian Islam dan Masyarakat, UIN Syarif Hidayatullah, 2018); Ayu Purwaningsih, "Why is Radicalism Growing among Indonesian Students?”, Deutsche Welle (11 Jun 2018), https://www. dw.com/en/why-is-radicalism-growing-among-indonesian-students/a-44159778, accessed 13 Oct 2018; Hadi Kuntjara, Kajian Kontra Terorisme dan Kebijakan: Radikalisme di Perguruan Tinggi Indonesia, no. 04 (Jakarta: The Habibie Center, 2019). 
year later. ${ }^{3}$ Can human beings live in a coexistence and peace, comfortablequiet-peaceful neighbourhood in a multicultural society, and equal social relationships which are unfortunately determined by so many different ethnicity, tribe, race, religion, skin colour? What type of human sciences is urgently needed in this contemporary multicultural era? I will focus the human sciences that are closely related to the religiosity of human being since this issue becomes a topic of the day, especially since the beginning of the Arab spring. Are there post-dogmatic types of religiosity which are seemingly more condusive to build a such non-conflictual type of pluralistic community? If there is a such religiosity, how is its theoretical frame work and its methodology? Can Islamic principles contribute to mediate this unavoidable difficulties? What type of human sciences do we want to build then? Could we construct intersubjectivity-nuanced types of religiosity, to reduce the tensions that are often acute between exclusive-subjective types of religiosity? Unlike a usual perspective, this paper is focused on the philosophical approach inspired by Immanuel Kant in his Perpetual Peace. ${ }^{4}$ I then developed this concept through approach of phenomenology of religion in religious studies. ${ }^{5} \mathrm{In}$ doing so occasionally I will refer to the Quranic verses when it is needed to substantiate the argument of progressive Muslim perspectives within the

3 There have been lots of books, articles, columns, freelance writing on a variety of local media, regional and international, public discussions, seminars, and research projects that emerged after the tragedy of September 11, 2001. It seems that the existing serious conversation reminds us that the entity of 'religion' is unavoidable thing to discuss seriously and critically like other sciences such as economics, politics, management, science and technology, and others. To discuss more deeply, see Ibrahim M. Abu-Rabi' and Ian Markham (eds.), 11 September: Religious Perspectives on the Causes and Consequences (Oxford: Oneworld, 2002).

4 On Kant's philosophical perspectives, I can say that Immanuel Kant (17241804) had ever written a book entitled Perpetual Peace. Another Kant's work which is important and relevant to this study is Religion within the Limits of Reason Alone. Immanuel Kant, Perpetual Peace, trans. by Lewis White Beck (Indianapolis: Bobbs-Merrill, 1957); Immanuel Kant, Religion within the Limits of Reason Alone, trans. by Theodore M. Greene and Hoyt H. Hudson (New York: Harper \& Brothers, 1960).

${ }^{5}$ Phenomenology is a kind of philosophical approach which was originally popularized by Edmund Husserl (1859-1938). On its way, it was then developed and used by the study of religions called an approach of Phenomenology of Religion. See more James L. Cox, A Guide to the Phenomenology of Religion: Key Figures, Formative Influences and Subsequent Debates (London: T \& T Clark International, 2006). 
frame of postmodernist approach.

The philosophical approach that I use is used to map and articulate three entities of types of religious thought in human sciences in a systematic way i.e.: Subjectivity, Objectivity and Intersubjectivity in human religiosity. This is different from the usual ways of Immanuel Kant's explanations of the profound differences between subjective and objective mindset in moral and religious area, and came out with the excellence of 'Moral Law', ${ }^{6}$ then I proceed to the phenomenology of religion. To my knowledge, it is a phenomenology of religion that develops the religious character of the 'intersubjective', i.e. the area of human religiosity that able to combine and articulate deeply, sincerely and intensively the sides of subjectivity and objectivity of human religiosity having been formerly considered to be mutually opposed, not to mention as a source of perpetual discord and conflict among religious followers. In Muslim tradition, this type of thought is nearly the same as what Tasawnuf, Sufism or Islamic Mysticism's thought in seeing the humanities. The only difference between both is their methods and approaches.

The discovery and appreciation of intersubjective dimension of humanity is hopefully expected by the elite religious leaders and followers to control their personal or communal emotions, to reduce its primordial sectarianism, to tolerate and understand the different subjectivity of human religiosity and civilization in general, accompanied by the awareness of religious objectivity that cannot be just ignored and negated behind the different subjectivity. Its negation will then create serious consequences for inter-religious co-existence. To maintain peace and mutual efforts to understand the differences between the various world religions and the various stakeholders as well as the customs and culture of human civilization requires new efforts both in the scientific, cultural, social or political manners. It is in this intersubjective territory that, with due regard of serious Objectivity and Subjectivity of religiosity, the concept of everlasting and perpetual peace in life and human civilization will possibly grow blossomed. Consequently, the term clash of civilization and the conflict within internal civilization, will become a myth and will then soon turn into partnership and cooperation between

${ }^{6}$ An in-depth elaboration on Moral Law can be found in Immanuel Kant, Critique of Practical Reason, trans. by Lewis White Beck (New York: Macmillan, 1985). 


\section{Amin Abdullah}

various given religions, cultures and civilizations that live abundantly in various parts of the contemporary multicultural and multireligion world. ${ }^{7}$

\section{B. Subjectivity of Human Religiosity}

In the academic discussions about religion and social relations between the religions, especially between Christians and Muslims, Richard C. Martin assumes the existence of (tension) between the supporters of Subjectivist and Objectivist groups. ${ }^{8}$ The tensions were exacerbated because the supporters of Subjectivity rest on the belief of divinity (fideistic subjectivism), while supporters of Objectivity rely on scientific perspective in looking at the reality of religious diversity in world religions (scientific objectivism). In the terms of Immanuel Kant, he distinguishes sharply between what he called 'Ecclesiastical Faith' (Kirchenglauben) which tends to be subjective, and 'Pure Religious Faith' (Reine Religionglaube) which tends to be objective. To Kant, pure religious faith is not opposed to, contrary or opposite choice of ecclesiastical faith. The ecclesiastical faith is a 'vehicle' for pure rational faith. To him, ecclesiastical faith is a 'skin' (shell) in which there is a core of rationality or intellectual side of religion, which he called Pure Religious Faith. ' Thus philosophically, as the science and other practical world, religion has

7 In Islamic studies, to my knowledge, a term which is slightly similar to Subjectivity and Objectivity is, Zanniyyat and Qat'iyyat. Of course, I cannot simply equate between the scientific discussion within the genesis of Jurisprudence and discussion within the philosophy of science. The reason is that the scientific jurisprudence is usually more focused on the textual area, while a discussion of Subjectivity and Objectivity in the areas of philosophy has a wide implication in the area of intellectual contemplation and reflection and critical analysis of the natures of culture, religion, society, civilization and so on. But lately, in the books of contemporary Islamic studies have begun to appear more equal terms to, not to say parallel, the Subjectivity and Objectivity i.e.: 'al-Thäbit' and 'al-Mutahawwil or 'al-Thawäbit' and 'al-Mutaghayyirät. Formerly, the two terms had also ever appeared, but they then disappeared and appeared again. The second re-start of the use of the two terms shows the development of contemporary Islamic studies area. See further Adonis, al-Thäbit wa'-Mutahawmil: Bahth fi al-Ittibä' wa'l-Ibdä' 'inda al-'Arab (Beirut: Dar al-Saqi, 2002); Iḥsān Tawfìq, Ba darānī, Thābit wa'-Mutaghayyir fì al-Sunnah wa'-Sìrāh al-Nabawyyah al-Sharifah (Damascus: al-Awā’il lil-Nashr wa'l-Tawzī', 2006).

8 Richard C. Martin (ed.), Approaches to Islam in Religious Studies (Tucson: The University of Arizona Press, 1985), p. 2.

${ }^{9}$ Kant, Religion within the Limits of Reason Alone, pp. 96, 98, 113, 126. 
two inseparable sides namely the area of pure theoretical reason and the area of practical-empirical (practical reason). A long time ago, a Muslim philosopher, al-Farabi (d. 950 AD) had also emphasized the same thing. He did not agree with the division and differentiation of science that are categorized as 'foreign' (imported; dakhil) and 'native' (original; genuine, domestic product) as some of the hard liners of Muslim today assumes. He agreed and strengthened over the division of science those are 'theoretical reason' and 'practical reason', ${ }^{10}$ so there should be no tiring debates on which one is more important between 'language' or 'logics' as it did in the days of al-Farabi, the debates between Abu Bishr Matta (870-940 AD) and Abu Said alSirafi (893-979 AD). ${ }^{11}$

What is 'Subjective' type of religiosity? From the study of religion, we can find subjective religious characteristics such as: 1) Normative. That is to look and see other religious groups of people's religiosities through the eyes of their own religious outlooks, not by the eyes of followers of other religious groups' ones i.e. measuring the size of someone else's shoe with our own shoe size. This normative view is often dogmatic-theological. In other words, the normative view of religiosity holds that only he and his group alone have the most worth, while the others are considered worthless. ${ }^{12}$ So, the nature or style of al-uqül al-mutanäfisah (polarizing sense or reason) towards the entity 'al-an $\vec{a}$ (Self) and 'al-akhar' (Others) always attached there. 2) Involvement (full engagement). Any full engagement as usually required by the preacher/evangelist, provider or transmitter of news or doctrine, leaders of religious organizations, and also religious

10 Paul E. Walker, "Al-Farabi on Religion and Practical Reason", in Religion and Practical Reason: New Essays in the Comparative Philosophy of Religions, ed. by Frank E. Reynolds and David Tracy (Albany: SUNY Press, 1994), p. 91.

11 Oliver Leaman, An Introduction to Medieval Islamic Philosophy (Cambridge: Cambridge University Press, 1985), pp. 9-13; Mohammed Arkoun, "Logocentrism and Religious Truth in Islamic Thought", in Islam: To Reform or to Subvert? (London: Saqi Books, 2006), p. 181.

12 Charles J. Adams, "Islamic Religious Tradition", in The Study of the Middle East: Research and Scholarship in the Humanities and the Social Sciences, ed. by Leonard Binder (New York: John Wiley \& Sons, 1976), pp. 35-7. 


\section{Amin Abdullah}

sect leaders to their followers are reasonable. ${ }^{13}$ The demand for full involvement is good, but it is sometimes unconsciously categorized into elements of fanaticism ('asäbiyyah; ta'äsub). If fanaticism has been involved, the 'emotion', then, slipped inside. In certain cases, when the emotion rose, then the unreasonable and uncommon actions cannot be prevented and controlled. ${ }^{14}$ Consequently, there emerge difficulties in distinguishing between the subsequent discussion of the Usül al-din (fundamental-essential things in generally and universally accepted religiosity) and Ușūl al-madhhāb (basic-fundamental subject-matters relevant only for particular, internal and sectarian groups). 3) Insider (insider perspective). Normative religiosity (read: not descriptive, as it will be described below), by itself will bring the religious followers' habit to see the reality beyond the self and religious group in the teachings of the religion itself (insider). It is really very difficult to train the religious insider and let alone be shifted, to try to look at the others through the perspective of 'outsider' with the help of scientific perspective (by using a set of theories, approaches, perspectives, methods, data and so on). 4) Certainty (qat iyy; absolute). Different from the scientific perspective that emphasizes probability, then certainty is something demanded by and from the religionists. In religion, truth and certainty seems inherent. The certainty is symbolized and reworded with so-called 'faith' or 'imān'. The further consequence and implication lead to the condition that it is rather difficult to distinguish between 'faith' (beliefs) and faith 'in tradition' (belief or faith in the historical and traditional practice of daily life). The possible result is that it is more difficult to separate between 'faith' and 'faith or belief arising from the individual and collective interpretation and understanding' (Ash'arite's interpretations are different from Mu'tazila's, and both interpretations were different from Maturidiyyah's; from Sunni's and Shiite's; interpretation of Imam Shafi'i and Hanbali; from Hanafi and Ja'fari interpretation, from the interpretations of the Catholic and Protestant traditions with various denominations and sects;

13 Ian G. Barbour, Issues in Science and Religion (New York: Harper Torchbooks, 1966), pp. 119-20, 226.

14 The role of emotion in religion can be more deeply elaborated further in John Bowker (ed.), The Oxford Dictionary of World Religions (Oxford: Oxford University Press, 1997), p. 1025. 
and from the interpretations of Hinayana and Mahayana groups and so on. 5) Apologetic-defensive. This style of religious thought normally produces apologetic religious literature which tends to defend itself and its group from any outside attack or criticism superfluously. As a result, its religious literatures and descriptions tend to be polemical and defensive at the same time. The religious descriptions and literatures with polemical-defensive-apologists types are quite reasonable to be produced and reproduced because they are used as a means to defend themselves from any external/outside attack from other religions' followers, socioreligious researchers and the internal religious denominations having different perspectives and scientific perspectives. ${ }^{15}$ The type and the style of religious argument is argumentum ad hominem (the demonstration of the believed truth), i.e. the religious arguments having patterns of religious offers that have been believed to be the truth and avoiding dialogue and criticism or refutation of his interlocutor. ${ }^{16}$ 6) Non-dialogical absolutist. The accumulation of patterns of thought and the religious attitude is the formation of mental attitude of human religiosity which is hard, absolute and rigid in dealing with various social issues especially political ones. These are the uncompromistic attitudes and religious views which do not recognize the concept of consensus, and will peak at no dialogical character. This austerity-absolute-rigid attitude is really needed because of insecurity either real or invented-imagined-engineered and accompanied by suspicion and prejudice against anything that comes from outside, mainly the ones that are more relevant or associated with religious social issues. Any selfish and communal senses that they always exist within the confines of the minority, though in fact is part of the majority, or the opposite, are really in minority (like the Muslim immigrant communities in Europe) but they think like a majority, indeed they inhibit the dialogues among civilizations. ${ }^{17}$ 7) Radical-Extreme. When the path of compromise,

15 The style of literature and ways of thinking that are apologists can be traced over the Wilfred Cantwell Smith, Islam in Modern History (Bergenfield, NJ: New American Library, 1959), pp. 91-4.

16 Josep van Ess, “The Logical Structure of Islamic Theology”, in An Anthology of Islamic Studies, ed. by Issa J. Boullata (Montreal: McGill Indonesia IAIN Development Project, 1992).

17 To have a special discussion on the majority's and the minority's problems, see Yvonne Yazbeck Haddad (ed.), Muslims in the West: From Sojourners to Citizens (Oxford: 
consensus and dialogue are completely closed and there are no other alternatives or, in other words, deadlock, particularly in matters relating to the issue of political interests and power linked with religion, so the accumulation of these various elements were going turn into the source of the recent religious movement touted as the extreme-radical one like the extreme ones who graced international relations among nations, ethnic and racial, inter-ethnic and inter-religious relationships in the world (religious trends, schools, sects, denominations, organizations) in various regions of this narrower planet. ${ }^{18}$

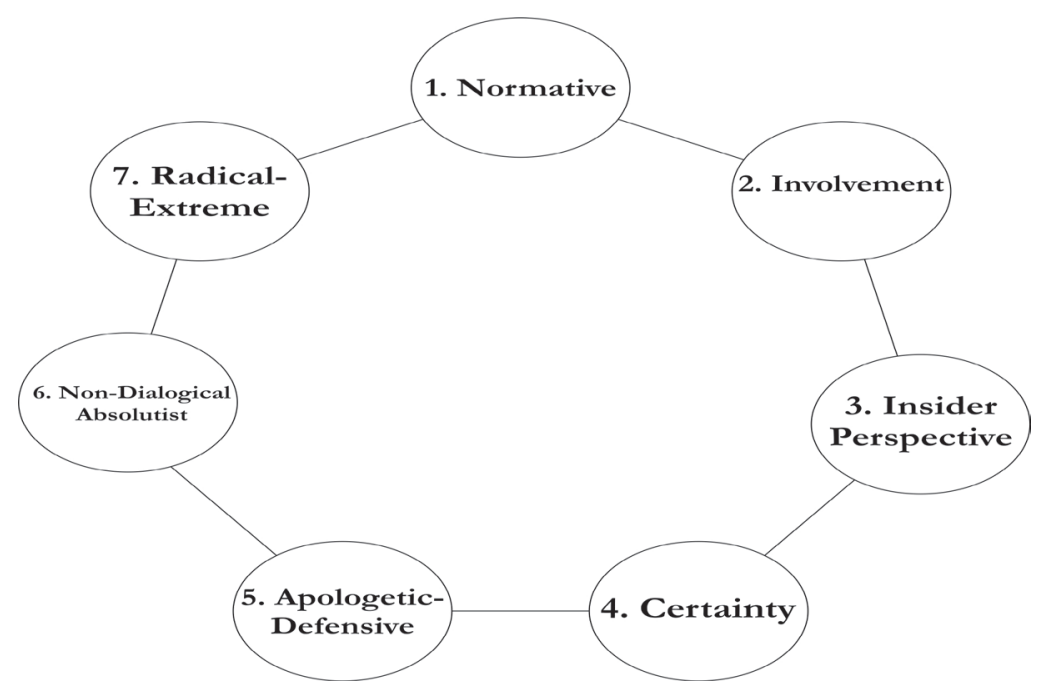

Figure 1. The fundamental features of Subjective type of religiousity

Teaching world religions at various places in the world in general still implement 'normative-subjective' types of religious education. Scholars of the religious studies call and classify the model of religious mindset as 'fideist subjectivism'. Some call it as al-'aql al-labüty al-siyäsy

Oxford University Press, 2002).

18 Abdullah Saeed, Islamic Thought: An Introduction (New York: Routledge, 2006), pp. 149-50; Ed Husain, The Islamist: Why I Joined Radical Islam in Britain, What I Saw Inside and Why I Left (London: Oneworld Publications, 2007); M. Amin Abdullah, "Introductory Elaboration on the Roots of Religious Violence: The Complexity of Islamic Radicalism”, in Innerer Friede und die Überwindung von Gewalt: Religiöse Traditionen and dem Prüfstand, 1st edition, ed. by Hans M. Barth and Christoph Elsas (Hamburg: EB-Verlag, 2007). 
(reason-divinity with political content). We can imagine how difficult we are in explaining religiosity and religions, if what we introduced to the students is 'only' the 'normative-subjective' model of education and religious instruction, which is more selfish or egoistic (not altruistic), and which is selfish and gives a priority only to their own sects, denominations or groups but ignores and even negates the existence of the other religious followers or the others (it can also apply to the other ethnicity, race, skin colour, gender etc.) as a companion to the world of peace (Dār al-Salam; abode of peace). Teaching such a model might be suitable only for themselves and their own internal groups and the world situations which are still sealed from the more open international relations today. But the model of subjective religious education can hardly contribute to the character of synergetic religious thought, and is unable to contribute ideas and provide a way out of the increasingly open world interaction among nations and followers of religions of the world (a greater interfaith interaction). Moreover, the subjective model of religious education can do nothing when faced with the reality of the existence of third parties (interest groups) who have always wanted to fish in murky water. The interest groups in politics, economy, society and culture are always lurking and at times could play the subjective-emotional-closed-rigid religiosity to achieve their own interests. ${ }^{19}$

Most conflicts in various parts of the world (Serbia, Bosnia, Somalia, Nigeria, Palestine, Ireland, Pakistan, India, Afghanistan, the Philippines, Southern Thailand, Indonesia (Ambon, Poso, Papua, Aceh, Medan), Egypt, Syrian today and others almost use the subjective normative religious factors as triggers and the driving motors. Moreover, we can mention any recent tendency of the rise of hard liners, radicalextremist groups of various world religions that clearly use of 'emotion' of denominational and sectarian religious groups based on the subjectivenormative-closed teaching style as a means of their struggle. For sure, this type of religious human sciences is very difficult to be maintained ans sustained for the peaceful coexistance and proexistence among the diverse religious followers in the world.

19 M. Amin Abdullah, Pendidikan Agama Era Multikultural-Multireligius (Jakarta: PSAP, 2005). 


\section{Objectivity of Human Religiosity}

Observing the patterns of thought, teaching models and subjective religious attitude, which seems to be less conducive to governance interaction between nations and mainly among the various followers of world religions in the planet getting smaller due to the advances in digital and transportation technology, the scholars of religion especially those that work in the areas of history of religions, and moreover phenomenology of religion, are forced to think hard to explain the objectivity of human religiosity, not only its subjectivity. Originally, social sciences such as anthropology, sociology, history and psychology here play an important role, which are later developed into social sciences of religion such as the sociology of religion, anthropology of religion, psychology of religion, and history of religions. Socio-religious scientists want to explain that the religious reality has subjective as well as Objective dimension. Religious objectivity is outside the will and desire of a person or group of followers (It exists autonomously out there). Social scientists want to explain religions and map the fundamental structure of the objectivity of religions, although in the historical practice their explanation and mapping are also highly dependent on the subjective 'interpretation' of their leaders and followers. Through the empirical scientific approaches obtained through (ethnological-anthropological) field researches, religious communities can not reject the fundamental structure of reality inherent in their own anthropological, sociological and historical realities of religions.

Religious objectivity can only be obtained by doing in-depth research. Research Institutions and Higher Educations are important in the study of Objectivity of human religiosity. Objective religious understanding has, among others, the following characteristics: 1) Descriptive-empirical. Most researchers explain any religion in accordance with what their respective religious adherents understand their own religions. Then, the researchers taped, recorded, classified, categorized and searched for any significant relationship between the findings and other data, and then interpreted them in accordance with perspective of social scientific studies of religions. 2) Detachment (a distance from the object of research). Unlike the views and attitudes, which ensures the need for full involvement in Subjective religiosity, what is needed here 
is the ability of researchers and a religionist to be fair in viewing and observing the fundamental structure of religiosity. To avoid and reduce biases of excessively subjective interests and religious understanding (as it is impossible to eliminate entirely in religious studies), then the role of the theoretical framework and research methods are very important here. 3) Outsider. Here religion researchers and religious men are no longer merely satisfied to be confined and trapped by the horizon of insider perspective (as what happens to Subjective religiosity) but they can also play them to see religions from the outside (outsider).$^{20}$ Here again, the necessary means are indispensable procedures and scientific approach called above as the sides of Objectivity or Theoretical Reason of the religion and do not stop on the side of the Subjective or Practical Reason (or often referred to as 'amaliāh') only. Here we can see the deep and wide contrast between the social sciences and the religious social sciences. Religion Researcher is indeed the figure of scientists who have religious experiences, but once equipped with the methodological tools and scientific approach to the reality of human religiosity that is very diverse. While the pure and true social researcher, not necessarily have religious experiences. Social researchers, in general, are supported by the sophisticated devices of methodology and scientific approach, but unfortunately they have less in-depth religious internalization and appreciation. Vice versa, the religious clergy and more elite leaders are required to have an objective attitude (scientific perspectives) in understanding the reality of religions. Generally, the clergy, especially the elites and leaders, are unable to take a position as a scholar of religions, because of their incapability of being stuck and trapped by their own religious subjectivity and their less experience as an outsider in a scientific perspective. It should be emphasized here, that an outsider does not mean as an outsider in the sense out of the religion he follows. ${ }^{21} 4$ ) Historicity. In the objective styles of religious views, there are clearly differences between the territories of faith and faith in tradition, i.e.:

20 Russell T. McCutcheon (ed.), The Insider/Outsider Problem in the Study of Religion: $A$ Reader (London and New York: Cassell, 1999).

21 For a comparison, see Kim Knot, "Insider/Outsider Perspectives", in The Routledge Companion to the Study of Religion, ed. by John Hinnells (London and New York: Routledge, 2005), pp. 243-58. 
the implementation and practice of faith in the history of humanity. In other words, the historicity (tärikhiyyah) of human religiosity is considered very important by the scientific descriptive style of explaining and understanding religions. Historicity, culture and tradition and habit of mind are very important in the science of religion, because all religions have formed, since their early establishment, their long historicity for centuries, and formed a strong tradition in their respective environments. Historically and anthropologically it can be described how the system and understanding of the rituals in religions were originated (Origin), then changed (Change) and further developed (Development), and the Language used as a tool of communication (socio-linguistics), and how were the patterns of socio-religious relationships (sociology) and systems of belief (anthropology). ${ }^{22}$ 5) Reductionist-relativist. There is criticism directed to the descriptive-empirical approach to the phenomenon of religion. One of them is too much emphasis on the external aspects of the religion. It's understandable, because the early generation of religion researchers was mostly derived from the traditions of positivistic social sciences. They had no trainings on more comprehensive-humanistic

22 The literature that emerged in the objective study on reality of religion was also in a remarkable development. To take some examples, we can mention the following literatures such as among others Donald S. Swenson, Society, Spirituality, and the Sacred: A Social Scientific Introduction (Ontario: Broadview Press, 1999); Michael Lambek (ed.), A Reader in the Anthropology of Religion (Malden, MA: Wiley-Blackwell, 2002); Keith A. Roberts, Religion in Sociological Perspective (Belmont, CA: Wadsworth Publishing Company, 1995); Meredith B. McGuire, Religion: The Social Context (Belmont, CA: Wadsworth Thomson Learning, 2002); Kate M. Loewenthal, The Psychology of Religion: A Short Introduction (Oxford: Oneworld Publications, 2004). Not to mention books like Peter Antes, Armin W. Geertz, and R.R. Warne (eds.), New Approaches to the Study of Religion, vols 1 \& 2 (Berlin: De Gruyter, 2008); John R. Hinnells (ed.), The Routledge Companion to the Study of Religion (London \& New York: Routledge, 2011). Those kinds of literatures, to my knowledge, are very rarely found in this country, Indonesia, not to say, in the whole Muslim world. I mean not only are they rarely encountered in Higher Education under the Ministry of Religious Affairs, but also in the universities and colleges under the auspices of Ministry of National Education. Indeed, it was difficult to find in-depth studies on religious studies of this model. As a result, the students in this country are not familiar with the study of religions in scientific-objective approaches. Moreover, they seem to be difficult in distinguishing between academic researches on the life of religions and evangelical activism movement or missionary (da'wa) activism movement, colonialism, and orientalism and so on. 
religious studies. It is the approach of phenomenology of religion that will fulfill this deficiency.

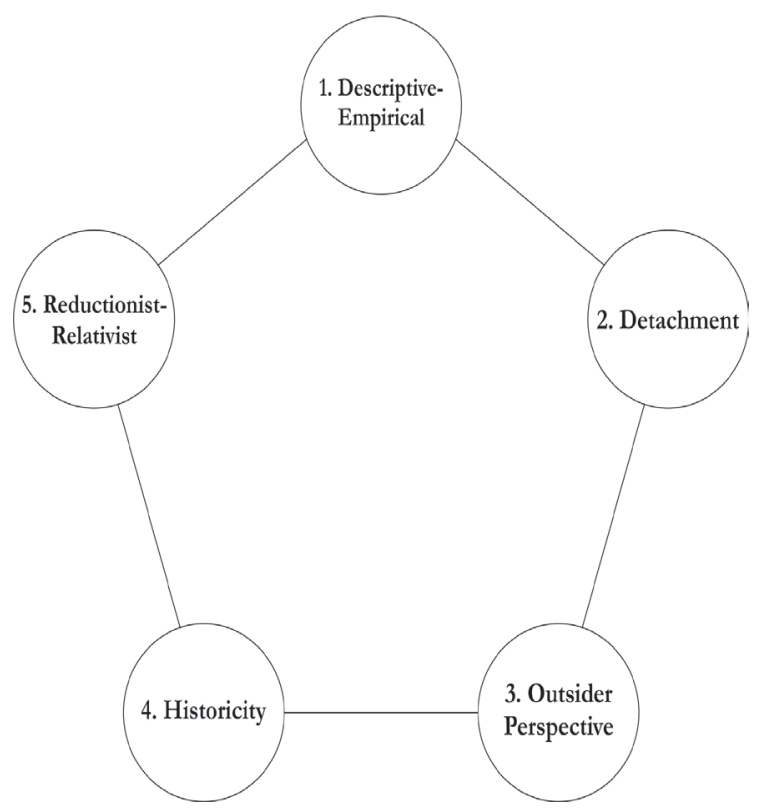

Figure 2. The fundamental features of Objective type of religiosity

There is a phenomenon easily observed in daily life of religiosity on the ground that the Subjective approach (fideistic subjectivism) and Objective one (scientific objectivism) in the study of religions does not know, talk and greet each other. Studies of Islam (or Christianity or Catholicism, Buddhism or Hinduism and so on) that are normativesubjective in different hierarchies do not recognize descriptive-objectivehistorical religious studies. While public education under the Ministry of research-technology and higher education (which should be more concentrated on the introduction of the objective religiosity-without negating the subjective one-does not do what to do. There is too wide gap between them. A teaching humanities and human sciences is still very difficult when confronted with the issue of religion and religiosity. What does it mean for the efforts of world peace through religions? If both, the character of normative-subjective religious education is so widely separated from the objective-scientific, and there are no mutual dialogues, relationships and greetings between the two, this will lead to 


\section{Amin Abdullah}

serious consequences in both the short and long term. At least, a possible result is the emergence of the 'narrowing' of the area of knowledge and religious experience (narrow-mindedness; group fanaticism; religious communalism), religious illiteracy and split of personality, the difficulties among educators, religious leaders and the elites of the clergy in general in determining attitudes towards the presence of the others around them. Religious illiteracy indirectly results in violations of religious rights guaranteed by the constitution. Moreover, there is a tendency of modern people who want to study religion in rapid-instant manner, through facebook, internet, instant sites, and do not bother deeply to get it. Then the subjective-normative-exclusive and instant approach is the only choice. The students and lecturers who pursue and focus on the sciences and technology, as well as the teaching of the conventional Islamic religious sciences ('Ulum al-din) are not so familiar with the discussion of comprehensive academic religious sciences from various perspectives, detailed and in-depth. ${ }^{23}$ Of course, the obtained styles and modes of religiosity are dogmatic followed by the fact that it will be very difficult to achieve synergy of religiosity among variety types of religiosity in the world religion.

A Muslim intellectual of Palestine, Ibrahim M. Abu-Rabi' once complained and wrote his observations as follows:

The absence of critical philosophy or social science perspectives from the field of Shari'ah studies can be illustrated by the fact that most students who acquire a government scholarship to pursue their education graduate abroad, especially from the Gulf States, only study the hard sciences or business administration, supposedly value-free or criticism-free subjects. In my many years in the United States (almost twenty years now), I have never encountered a single student from the Gulf pursuing a graduate degree in political science, philosophy, or history. Closing the door to any type of critical perspectives has been the underpinning of the field of Religious Studies (especially 'Ulüm al-dìn: mine) and made it quite irrelevant. This fact has made it quite difficult in many Arab countries to encourage the growth of a scientific tradition, developed mainly in the West, to study the complex interplay between religion and society in the modern Arab world. The discipline of the sociology of

${ }^{23}$ Khaled Abou El Fadl, The Great Theft: Wrestling Islam from the Extremists (New York: Harper Collins, 2007), p. 171. 
religion is looked upon as a heretic, or innovation, that does not convey the real essence of Islam. Just like the study of the modern Arab state system, the Sociology of Religion is a necessity in the Arab world. ${ }^{24}$

The students and lecturers who receive scholarships and mainly the ones who are in their own, they like more practical things and can be practiced immediately, without any in-depth reflection. Religion of the modern era is drought, dry and even loss of fundamental-spiritual values that can sustain a plural togetherness. Both the subjective and the objective types will fall into the reduction of externalities and simplicities with their own version and as if each of them went into a paradox and a dead end. Human beings are not satisfied with these recent phenomena in understanding humanity and religiosity as stated in quotation above by Nidhal Guessoum. ${ }^{25}$ So what do religion scholars attempt to face stagnation of contemporary religious and Islamic thought, especially to cope with the demands of global world peace and synergistic relationship between the various nations and followers of various religions in a multicultural society? How do they attempt to do the shifting paradigm of dogmatic religious complexion leading to post-dogmatic one? It is indeed the challenge of our contemporary humanities and human sciences as well.

\section{Intersubjectivity of Human Religiosity: Toward a Post- Dogmatic Religiosity}

Multireligious and multicultural society in a nation-state having a slogan of Unity in Diversity (Bbinneka Tunggal Ika) such like Indonesia is a socio-political reality that can not be denied. Diversity not only in the religion but also in ethnicity, race, culture, and language. It is not only in Indonesia, buat also elsewhre in the world. It is not by accident that the United States of America, a long time ago, also used a similar

24 Ibrahim M. Abu-Rabi', “A Post-September 11 Critical Assessment of Modern Islamic History", in 11 September: Religious Perspectives on the Causes and Consequences, ed. by Ibrahim M. Abu-Rabic and Ian Markham (Oxford: Oneworld, 2002). I Italicize, bold, and insert the word 'Ulum al-din myself.

25 Guessoum, Islam's Quantum Question, pp. 343-4; Ninian Smart, "The Global Future of Religion", in Global Religions: An Introduction, ed. by Mark Juergensmeyer (Oxford: Oxford University Press, 2003), p. 127. 


\section{Amin Abdullah}

token: E Pluribus Unum. Ways of thinking, communicating, associating and socialization in a nation-state based on the constitution are different from the ways of thinking, communicating and associating in the era of theocracy and monarchy. Equal citizenship or equality before the law is one feature of the life of the nation-state era and indeed the humanity today. The nation-state after World War 2 is also different from the previous one. The nation-state after World War 2, mainly after the establishment of the United Nations, mainly its members was also bound by a collective agreement that was set in the world board. In the post-establishment of the United Nations, the history of human civilization is bound by three values simultaneously, namely the values of the local religious traditions, the values of the nation-state and values of world citizenship. The demand of constitution in the nation-state is very different from the demand of religious teachings, which generally gives more priority to their own religious groups. The integration of these two values is not easily to be done and not all citizens are ready to accept it. This is the challenge of our contemporary humanities and human sciences as well.

Perpetual peace and the synergy of religiosity in a multicultural society requires the need for radical changes and transformation in one's religious views and the groups', because there is no world peace without peace between leaders and followers of religions, 'no world peace without religious peace', said Hans Kung. ${ }^{26}$ Some even say that 'al-istibdad al-siyāsy mutawallid min al-istibdad al-diniy' (political dictatorship is born of religious dictatorship). ${ }^{27}$ Truth claims which used to be the beliefs and attitudes of followers of subjective-dogmatic-exclusive religions (ecclesiastical faith) became a source of trouble and the first stumbling block for the followers of any religion to perceive and appreciate the presence of people and followers of other religions (the others; al-akbar). They experience tremendous obstacles to be able to understand, see and feel as it is understood, seen and felt by people and other groups themselves (self; al-ana) with complete and appropriate rights and obligations. The values

${ }^{26}$ Hans Kung, Christianity and the World Religions: Paths to Dialogue with Islam, Hinduism, and Buddhism (Garden City, N.Y: Doubleday, 1986), pp. 440-1.

27 Abdulrazzaq Id, Sadanah Hayakil al-Wahm: Naqd al-Aql al-Fiqhi (Al-Buti Namudhajan) (Beirut: Dar al-Tali'ah, 2003), p. 6. 
of the new life giving more principles of non-discrimination in any form either in religious life, social, economic, political, and cultural one, without prejudice (prejudice; su'u al-zan) between fellow religious communities, ${ }^{28}$ a view which is equal between the followers of various religions before the law in the nation-state, and the view that the followers of other religions are companions who help each other in achieving a common good and in dealing with the difficulties of living together (partnership) becomes difficult to seed. The values of civility is extremely important to sustain Perpetual Peace (eternal peace, unconditioned perpetual peace) coveted by all community members of the world religions' followers. Indeed, the values of humanity and civility are needed to build synergy between different religious communities in a multicultural society.

The perspective and religious philosophy in a multicultural society necessitates the need for renewal of its methods and approaches in religion education, humanities and human sciences nowadays, i.e.: the religion education which is much more responsive and sensitive to the values of humanity and civility ${ }^{29}$ in responding the need for a greater interfaith interactions and the closer relationships between the nations of the world, inter-ethnic, racial as well as careful to the development of thought of the inter-religious at the local, regional and international or global levels. This new sensitivity is highly needed to make education in human sciences and religious teaching still relevant to the ongoing societal development beyond the wall of the curriculum and syllabus that seems to have been standardized by the state or by religious organizations or by individual initiative. In the academic and scholarly world, especially in the area of religious studies, Islamic studies and human sciences, the inisiative and the contribution of the approach of phenomenology of

\section{Qur'an, 49: 12,}

29 The new Muslim intellectuals, such as Jasser Auda, Mashood Baderin, Abdullah Saeed, to mention only some of them, are seriously strifing to introduce a new type Islamic education which is much more sensitive to the common good and the right of others. Jasser Auda criticizes the traditional type of Maqasid of Syari'ah (The purpose of Syari'ah) which is only sensitive to specific and partial Maqasid, but less attentive and sensitive to the general Maqasid, such as justice, freedom (religion and belief; expression, association), equality before the law. See Jasser Auda, Maqasid AlShariah as Philosophy of Islamic Law: A Systems Approach (London: International Institute of Islamic Thought, 2008), pp. 4-7. 


\section{Amin Abdullah}

religion is deserved to be seriously considered.

Phenomenology of religion is an approach in religious studies that is very much concerned with the solving difficulties inherent in the subjective-normative-exclusive type of learning and the type of approach to the religion as exemplified by ecclesiastical faith, in one side, and merely pure objective-descriptive-scientific (pure religious faith), following Kant's classification, in the other side. Those two approaches are less in the spirit and ethos to establish peaceful, non-conflictual coexistence and perpetual peace in various parts of the world. I would like to call the scholarly endeavours to bridge the gap between the two types of approach as 'Intersubjectivity' type of religiosity. ${ }^{30}$ The intersubjective approach of phenomenology of religion wants to understand the beliefs of other groups, sects, denominations or organizations, appreciate, tolerate and fully recognize their existence. Each religion and belief (subjective) has a full right to life unconditionally. It is always aware of that each religion and belief should not stumble towards the rigid, exclusive, and unhealthy dogmatic truth claim. Therefore, in addition to pay attention to and strengthen the subjective side of religiousity, it also pays attention to strengthen the objective sides of religiosity embedded in the history of mankinds. From historical point of view (historicity; tarikhiyyah), the existing religious traditions and belief in all over the world cannot be denied.

Historical religions which are full of 'interpretation'-not to refer to it as 'interests'- of the leaders, religious leaders, party leaders, the ruling officials, scholars, clerics, teachers, professors, monks, priests, pastors, intellectuals, and also grass roots or laymen. Historical side that cannot be avoided from a forming process (origin), change and development in accordance with local, regional and international challenges faced by the context of era, political, social, and cultural situations and as

30 The term 'Inter-subjectivity' is borrowed from Barbour, Issues in Science and Religion. The Book is good enough in the area of philosophy of science of religious sciences, which is very different from the descriptions of the philosophy of science in general, because of its encounter with religious areas. The book is also very rarely read by religions educators of traditional patterned-conventional and even modern ones. Then, the term 'inter-subjectivity' is further developed in the tradition of Phenomenology of Religion in the perspective of Religious Studies. 
well as intellectual levels developed in a particular era. ${ }^{31}$ In the end, phenomenology of religion will underline the existence of the Common patterns (al-Thawäbit) among the existing religions and also confirms the presence of Particular patterns (al-mutaghayyirät, al-mutahawnilät) wrapped in historical traditions of the world religions. Struggle, debate, deep discussion and dialectics between the two will lead to the formation of attitude and a new view called empathy and sympathy among fellow followers of various religions. This basic and genuine character is a psychological condition of sincere relationship among the followers of diverse religions towards the formation of new values of humanity and civility that lead to the formation of post-dogmatic religiosity, peaceful coexistence, integration, synergy of religiosity and the alliance between civilizations.

\section{Common Pattern and Unique Pattern in the History of Religions and Ideas}

In the experience of daily life, people and society in general cannot deny the reality of religious diversity. Diversity and plurality are inevitable. Each religious follower claims that his own religion is the truest (truth claims). The characteristic of the subjectivity of religion has been described above with 7 (seven) tendencies inherent in it. To reduce tensions among various unilateral claims, then phenomenology of religion offers concept and approach of religion which intellectually-rationally can clearly distinguish the unchangeable sides or common/universal pattern (al-thawäbit) which are not changing in religions and the changeable sides, special or unique, which cannot be compared at all (particular/unique pattern; al-mutaghayyirat) from other religions. The differences between the two can only be understood and mapped through fundamental-radicaldepth intellectual ijtihäd (reasoning, use of Logics; say not just through

31 In the Muslim context, here, I borrow the term used by Ahmad Amin who sees and shares periodization of historical development of Islamic thought and culture into Fajrul Islam (Origin), Duha al-Islam (Change) and Yawm al-Islam (further development). If in the internal history of the development of Islamic thought and culture can be explained in such a historical approach, so can the history of ideas and cultures of other religions. It can also happen to a cross and the struggle between the world religions in the history of more complex world civilization. 


\section{Amin Abdullah}

a language or lughah),,$^{32}$ and sharpness of insight and depth of genuine spirituality. While the changeable sides of religion, specific-unique-typical types of religiosity, or al-mutaghayyirät, can be well understood through the activities of research (diligent, systematic and in-depth field research) by following the rules, methods and research steps that have been formulated by the experts. Empirical, historical, sociological, anthropological or psychological research must be suitable to geography of different birth places of religions, languages used and the socio-economic-political condition when a religion appears (Origin), following the Change and the further Development experienced by the followers of the religions in the course of its long history. The terms of Common pattern and Unique pattern used here is actually rather equivalent to the terms of subjective and objective above, but with a different pressure point. The pressure or focal point that phenomenology of religion underlines is that the contemporary religious studies have always to consider the two entities involved in the inseparable integrity of thinking and attitude. In other words, religious studies through phenomenological approaches always assume that the study of religions is always subjective-cum-objective or objective-cum-subjective. A serious and intens dialogue between both is the basic characteristic of phenomenology of religion. To split diametrically between the two is not a genuine religious study.

\section{Epoche (German)}

Epoche is the ability of a person or group to be sincere and selfrestraint and self-regulation for not expressing statements which are harming, demeaning, degrading, considering the others as infidels, apostating, or hurting another group in any forms. The desire to issue the statements should be delayed or postponed. ${ }^{33}$ The negative as well as

32 The role of Logics in shaping the religious mindset, especially against Kalam mindset in Islam, can further be seen in Ess, "The Logical Structure of Islamic Theology". It can also be compared to Mohammed Arkoun, Islam: To Reform or to Subvert? (London: Saqi Books, 2006), p. 181.

33 When writing this paper, I recall to re-elaboration on the Qur'an unconditionally reminding the faithful Muslims not to insult, not to slander and vilify each other between one group and another. Even it is also reminded that it could happen that the group or groups or individuals who were insulted, vilified in public, tainted, removed earlier were better than those who insulted, vilified and mocked at. 
positive statements and judgments addressed or directed to persons or groups of other religions and their religious communities are postponed. In other words, this technique of epoche is to reduce the involvement and complicatedness of uncontrolled and not publicly accountable and rational emotions. This epoche technique is not only limited and applied to the area of religion, but also includes the race, ethnicity, clan, gender, class, ethnicity, age group, education level differences, to difable persons and so on. The practical usefulness of the techniques of delaying or refraining (temporarily) not rush to judge another person or group is to obtain a clearer perception, complete, comprehensive, undistorted, and untainted by bias of any interest. This step is in a sharp contradictory with a hate speech blossoming of in social media to judge other groups as apostate, infidel, astray, going to hell in our contemporary Muslim daily life.

\section{Eiditic Vision}

To find the essence, substance, and the fundamental structure of religions is not easy. The phenomenologists call the search eidetic vision. Giving the layered curly brackets sign \{\} , followed by the other brackets [] and followed by the next () and so on towards the various forms of information, reports, news, accusations, social gossip about other beliefs and faith from any source (in Islam: tabäyun). Eidetic vision is the actual searching step of fundamental structure, essence, substance or nature of the deepest of human religiosity, i.e. questioning and distinguishing which one is the skin and what is the content; which one is the shell and what is the kernel; which one is universal, common pattern and which one is particular, particular pattern; which one is the shared values and the distinctive value. This is not easy, because human nature always wants to take a shortcut, the easiest way, which do not need to do in-depth reflection. Naturally, historically and sociologically, human religiosity is very different between one and another. Religiosity, belief or faith that is believed by another person or group is very different from what we have and we believe in absolute truth (certainty) so far. From here it is also

See further Qur'an, 49: 11-12. 'O who believe! Let not some men among you laugh at others; it may be that the latter are better than the former...and so on". A clause whose content and message are parallel with what is desired by the phenomenology of religion. 


\section{Amin Abdullah}

understood that there is no similarity in religions in the world because of their respective long history. However, behind those diversities there exist fundamental structures on it which acan be analysed and understood.

\section{The Historicity of Religion}

Phenomenology of religion gained valuable input from objectivescientific religious studies. It is not phenomenology of religion if it does not use accurate data collected and discovered through in-depth historical-empirical research by a variety of scientific methods and approaches to socio-religious phenomena. The method of scientific approach which use the principle of evidentalism -evidence-based policy and evidence-based way of thinking- is the most important feature of modern phenomenology of religion. Let be taken from the history of religions, sociology of religion, psychology or anthropology of religion. The area of al-mutaghayyirat or particular or unique pattern can only be clearly understood if phenomenology of religion examines the collected data and facts. It has been assumed that there are at least seven (7) dimensions that can be found in the field research in the historical-empirical religious life, whatever the name of that religion is. First, every follower of religion certainly performs certain activities on a regular, routine and repetitive basis (Ritual; worship; figh al-ibädah); Second, believe in a certain thing (a system of faith, belief or dogma); Third, honour and glorify the leaders who considered to be authoritative (the Prophet, apostles, down to the level of cleric as heir to the prophet); Fourth, respect the holy books (Qur'an, Bible, Torah, Psalms, Veda and so on); Fifth, have a history of the heroic founding fathers and chain of sustainability for future generations until the present time (tärikh, sirah, pedigree); Sixth, have a code of ethics and moral systems that can be used as a reference for adherents' legitimate behaviour (morality, akblāq), and Seventh; supported by a solid institutions (social institutions, education, politics) ${ }^{34}$ Once again, seen from this description, it can be ensured that there is no religion that is same and similar in this world. Each religion is unique, distinctive and cannot be generalized for granted. It is too hasty and complicated to assume that all religions are the same. The claims

${ }^{34}$ Cox, A Guide to the Phenomenology of Religion, p. 236; Ninian Smart, Dimensions of the Sacred: An Anatomy of the World's Beliefs (London: Fontana Press, 1996). 
or even the allegation were not supported by any convincing evidence academically. Even theologically, Islam discredits the hasty claim. ${ }^{35}$ Those which are similar or especially resemble (family resemblance) between the large family of different religions are the belief systems and socioreligious systems that sustain their existence, which among other things are characterized by 7 (seven) dimensions described above. The seven dimensions can also be added and subtracted in accordance with the developments of field research. Therein lays the importance of particular or unique pattern or al-mutaghayyirät in religions. Here also lays the point of separation between the social science approach to religion which is only satisfied with the sides of the externalities of religions (reductionist) ${ }^{36}$ while the approach of phenomenology of religion always involves the postulation of factors of 'non-falsifiable postulated alternate realities ${ }^{37}$ (it is assumed that there is the existence of non-falsifiable/undoubted alternative Reality) attached to the world religions. It is the last factor that has made the human religious issues more complicated and complex on the world stage because they are stucked on theistic or fideistic religious subjectivity discussed above.

\section{Verstehen (Understanding-in-Depth)}

After recognizing that the reality of human religiosity is very complex, and simply cannot be separated from highly viscous factors of subjectivity, even they are non-falsifiable (cannot be blamed, no doubt, cannot be falsified), all of us are too aware of and understand that subjectivity of religiosity is also inevitably and strongly bounded in human

${ }^{35}$ Cf. the Qur'an, Sürah al-Mäidah, verse 48 (verse 51 in Abdullah Yusuf Ali's The Holy Qur'an): "To thee We sent the Scripture In truth, confirming the scripture that came Before it, and guarding it. In Safety: so judge Between them by what God hath revealed, And follow not their vain Desires, diverging From the Truth that hath come To thee. To each among you Have We prescribed a Law and an open Way. If God had so willed, He would have made you A single People, but (His Plan is) to test you in what He hath given you: so strive As in a race in all virtues. The goal of you all is to God; it is He that will show you the truth of the matters in which ye dispute." Abdullah Yusuf Ali (tran.), The Holy Qur'an: Text, Translation and Commentary (Beirut: Dar al Arabia, 1989), pp. 258-9.

\footnotetext{
36 Adams, "Islamic Religious Tradition", p. 46.

37 Cox, A Guide to the Phenomenology of Religion, p. 236.
} 


\section{Amin Abdullah}

historicity. In addition, scholars are also aware of the religious sides that cannot be separated from its side of objectivity (Pure religious faith, according to Immanuel Kant's terminology), which is only understood through intellectual ijtihäd and sharp logics and depth of genuine insight, then phenomenology of religion raises new requirements for the study of world religions i.e. verstehen. Verstehen (German) is an attempt to understand the nature and existence of other religions seriously and sincerely, not judging followers of other religions (value judgment), nor blaming, mainly considering the others as apostate or infidels. Contemporary religious studies and religion educationists which are expected to contribute towards perpetual and eternal peace and synergy of religiosity can only be achieved if among fellow leaders, elite leaders, and followers of world religions that vary between different cultures and civilizations of different world-difference, between the various ethnic, racial, ethnic and so on give more priority and precede over spirit, fundamental desire and willingness to understand each other sincerely (verstehen $)^{38}$ and recognize (al-ta'äruf) any differences and similarities: not judging one another, deriding, insulting each other, and discrediting, discriminating, marginalizing and degrading each other, claiming its own right or claim, feelings of superiority above or inferiority below, misunderstanding and not respecting the others (individual or group). It is here that the universal principle of reciprocity applies (the need for mutual recognition, to understand each other's feelings and thoughts of other people or groups, mutually reinforcing and strengthening solidarity among fellows against injustice, discrimination, abuse of power and so on.

In terms of this important issue, a phenomenologist of religion believes that all life (bayāb; life) of human beings including their beliefs, faiths and belief systems and procedures are very significant (meaningful) and valuable to individuals and groups who believe in and have it.

38 Verstehen is a technical term of humanities which underscores the importance of "the comprehension of ideas, intentions, and feelings of the people through the empirical manifestations of culture. The Verstehen method assumes that human beings in all societies and historical circumstances experience life as meaningful, and they express these meanings in discernable patterns that can be analyzed and understood". Furthermore, see Richard C. Martin, "Islam and Religious Studies: An Introductory Essay", in Approaches to Islam in Religious Studies, ed. by Richard C. Martin (Tucson: The University of Arizona Press, 1985), p. 8. The bold is mine. 
Derision, insult, cynicism, sarcasm and mainly violence directed against the others are completely contrary to the spirit and social ethos to be seeded by phenomenology of religion. Such things like the actions and attitudes that prefer a desire to truly understand the feelings, thoughts and beliefs of other people or groups are 'unconditioned', similar to the spirit of enlightenment proposed by Immanuel Kant's ethics. This is precisely what he refers to as 'Pure rational faith' (reine Religionglaube) which is the 'kernel (core; innermost side) of religions rather than the 'Ecclesiastical faith' (Kirchenglauben) or 'shell' (the outer skin; externalities) of religions. It was such these things that Kant expected 200 years ago when dealing with the socio-political crisis mixed with acute religious conflicts between Catholic and Protestant in Europe after the rise of the Protestant religious movement of the 16th century and before and after the French revolution of the 18th century. Kant's difficulty and anxiety, has now increased many times, because the intens encounter between the nations and followers of religions increases in more complex and complicated way as it involves a variety of actors with sources of injustice in the world economy and in the science and technology.

\section{Empatby and Sympatby}

Humans should not despair, says the Qur'an. Flows of thoughts to resolve religious issues should continue to be pursued. If the shortage and scarcity in the area of food and then encourage people to think hard to cope with taking breakthroughs in the field of creating highbiotechnology, then the scarcity and deficiency in the religion as well as the humanities was supposed to exist. New creative-innovative thoughts to solve the complex problems the religious communities should continue to be pursued by anyone, especially by experts and elite leaders. Completion of previous models that are no longer relevant should be reviewed, improved and perfected. The purely subjective religious approach and just stopped at the objective alone apparently cannot penetrate into the heart of the difficulties of inter-religious life let alone get to the level of solution. It seems that perpetual peace, peaceful coexistence and nonconflictual proexistence are still far from the expectations of all who desire them.

Phenomenology of religion, as a methodology in human sciences, 


\section{Amin Abdullah}

is about to break through the geological crust of religious thought and belief that has hardened and turned into a very hard granite rock along with its increasing time. Religious concepts (theoretical reason) and the healthy procedures of religious thought (practical reason) need to be continuously searched together. Without pretending to have to change the belief systems and religious beliefs as long as this has been believed and held down by its adherents, experts of phenomenology of religion want to underline and add a genuine need for awareness that there do exist 'the others' (The existence of the others who have the same rights and obligations as the others owned). There has also been a set of rights such as freedom of religion and belief, thought, expression and association ${ }^{39}$ having been recognized and agreed by world institutions like the United Nations and supported by the International Law. Understanding a set of rights having been ratified by the nations of the world is the common task for all religious intellectuals today to deal with. In Muslim context, this task is commonly referred to the need of having a new social Figh. It is the social Figh or a new social Islamic understanding that will collaborate with phenomenology of religion (through the epoche and eidetic vision techniques) that will be able to delve and penetrate the geological crust of frozen religious thought and belief. ${ }^{40}$

The peak and keyword approach of phenomenology of religion is the need of cultivating and planting a sense of sympathy and empathy among fellow human beings and among people and also members of the world religions (the Others). Feelings of pain, fear, anxiety, elimination, persecution, marginalization, and discrimination as perceived by another person or group - regardless of minority or majority - the same feelings and sufferings can also apply to our own self and groups. We can also experience the same feelings and our response was not much different from the feelings experienced by people who are considered as the Others. Therefore, such advocacy is underlined by phenomenology of

39 For further discussion, see Mashood A. Baderin, International Human Rights and Islamic Law (Oxford: Oxford University Press, 2003).

40 Again I refer to Jasser Auda's proposal for having a renewal understanding of social figh, using a systems approach. To have this renewal implementable, six elements are needed to be combined and integrated in a systematic way, namely cognition, wholeness, openness, interrelated hierarchy, multi-dimensionality and purposefulness. Auda, Maqasid Al-Shariah as Philosophy of Islamic Law, pp. 192-245. 
religion, so that there appears an expression that Empathy perpetuates distinction between the subject and object (the spread and growth of sense of empathy and symphaty in a person or group can actually bridge and even melt gaps and barriers of sharp distinction between subject and object; (read: among Muslims and non-Muslims or among various groups within the Muslim culture itself (al-Firāq al-Islamiyyah).

\section{Inclusive-Partnership-Dialogical}

The Epoche and eidetic vision technique including another following procedure was still meaningless for efforts towards perpetual peace and synergy of religiosity if it is not forming a new mentality, a new religious mindset, a new ethic of religious life that is more dialogical, cooperative, participatory and inclusive. The future of religions in a multicultural society is largely determined by the social ethos of new human ethical value. Indeed, it is not easy for individuals mainly a group of individuals to get into the stage or level (maqäm), because it is the result of tafkik or positive deconstruction which is continuously and sustainably performed with patience towards the granite crust of Subjectivity of religious thought that has been strongly applied and frozen. A dialogical manner means that among members of community groups and interpersonal elite religious leaders can meet and have a dialogue on an equal basis to discuss common difficulties faced by human beings in any region leading to a situation that there happen intensive, friendly and equal communication among them, eliminating the communication gap and reducing prejudice (süu al-zan) among various religious groups. ${ }^{41}$

It is only by empathy and sympathy that the process of genuine dialogue can take place. Inclusive-integrative type of thought can take place only if it is preceded by emphaty and symphaty. Thus, religious people always do not forget the absence of people, group, community or other communities outside of themselves, group and faction. Not only does this rule applies to the external areas of religious community, but also applies in relation to internal religious adherents. Without having

41 The new initiative by Muslims, in the eve of 21 century, for having a serious and continuous dialogue with Christians, see Waleed El-Ansary and David K. Linnan (eds.), Muslim and Christian Understanding: Theory and Application of 'A Common Word' (New York: Palgrave Macmillan, 2010). 


\section{Amin Abdullah}

this attitude, what we have is only a deficit in every truth. ${ }^{42}$ We always involve the Others in any matters related to public issues. This group of the others has always been an inseparable part of our entity. Then, there is no longer the term 'the Others' (al-Akhar) in the old sense segregated and separated away from us. If the meaning of the Other was still in the old sense, consequently the politics of segregation, discrimination, marginalization, subordination, and elimination will certainly reappear. Authentic human values will not be appreciated and the conflicts will still arise. While moderate and participatory partnership intended to establish a genuine and equal unity, will always involve groups of different religions together to solve the more increasingly acute problems of humanity; we could find problems concerning the public goods, which among others include drug crimes, poverty, environmental problems, global warming, climate change, child and women trafficking, abuse of power in the forms of corruption, collusion and nepotism, violations of human rights and much more.

Through epoche and eidetic vision of human values (virtues kindness) hopefully we will catch the following virtues such as: a charity (charity goodness; willingness to do good unconditionally), compassion (alrạmān, al-rahìim), honesty, fairness (justice), equality (equity; al-musāwāh), tolerance (al-tasamub), altruistic (put the interests of others earlier), mutual respect (respect; ị̣tirām al-ghair, al-tà'äruf), mutual trust, humility and awareness of boundaries owned by humans (humility; self-restrain), prioritizing patience in solving various problems of social-humanitarian (forbearance; al-sabr); willingness to forgive (al-'afw; forgiveness); discipline (self-discipline; self-regulation; zabt al-nafs); giving priority of moderate way and attitude (al-tawärun; al-tawassut) and the problem-solving patterns of street violence (non-violence; al-unf; al-ghuluw wa al-tațäruf), physical, psychological, social, cultural and mainly religious violence.

42 Lieven Boeve, "The Particularity of Religious Truth Claims. How to Deal with It in a So-called Postmodern Context", in Truth: Interdisciplinary Dialogues in a Pluralistic Age, ed. by Christine Helmer, Kristin De Troyer, and Katie Goetz (Leuven: Peeters, 2003), pp. 192-5. 


\section{New Enlightening Religious Mentality (al-'aql al-jadìd al-istitlāa'i)}

After discussing the implications and consequences of subjective patterns of religious thought (al-'aql al-labüty al-siyassy; politics-nuanced pattern of divine-reason) and also after considering the implications and consequences of objective religious models of thinking and analysis (al'aql al-tärikby al-ilmy; scientific pattern of religious thought), and after looking earnestly that religious entities and even its existence cannot be underestimated and underrated entirely in human life anytime, anywhere and in any era-this is contrary to the thesis of the modern sociology of religion of the positivist era (August Comte) which predicted that religious adherents would leave their religions once the human beings entered into the highest level of progress of human civilization, phenomenology of religion here offers another thesis. Religion is very significant (meaningful) for the adherents of any religions; there is no linear evolution in religious life where those who come later are guaranteed to be better than those coming earlier, then it is the religious studies of the new era oriented to the achievement of perpetual peace. A type of religious studies which have practical implications for the life together that can deliver its followers to a mutual respect and mutual trust and ensure the realization of a peaceful life side by side and continuous synergy of diversity. From now on, religious people, especially their elites, should be well-trained and familiar with seeing and observing the reality of pluralistic society and religion from the 'divergence', not merely from the 'convergence' perspective.

Just as the natural and social sciences always developed through continuous research and further development by using and utilizing new theories and approaches, so did the religious studies, Islamic studies and human sciences as well. Even the need for its development should be a more urgent to do. Phenomenology of religion wants to encourage and develop a type of religious thought and behaviour into a more enlightening and progressive. A new era for the enlightenment for all stakeholders in the internal circles of religion itself (insider) and outside of the religious and social observer (outsider) as well as the implication and the consequences of having intens interactions and encounters between insider and outsider. This new mindset is simply called mentality and attitude of a new enlightening religious attitude (al- 
'aql al-jadid al-istitlā $r)^{43}$, not dogmatic-exclusive-closed type of religiosity (al-aql al-diny al-taqlidy), let alone mentality, behaviour or attitude of radical, extreme and violence type of religiosity (al-aql al-diny al-'unfy-altatärrufy). Processes and procedures of way of thinking, state of mind of this new religious mentality and the working procedures that have been described above will color and determine the global peace of humanity and the future of the world's religions in multicultural era.

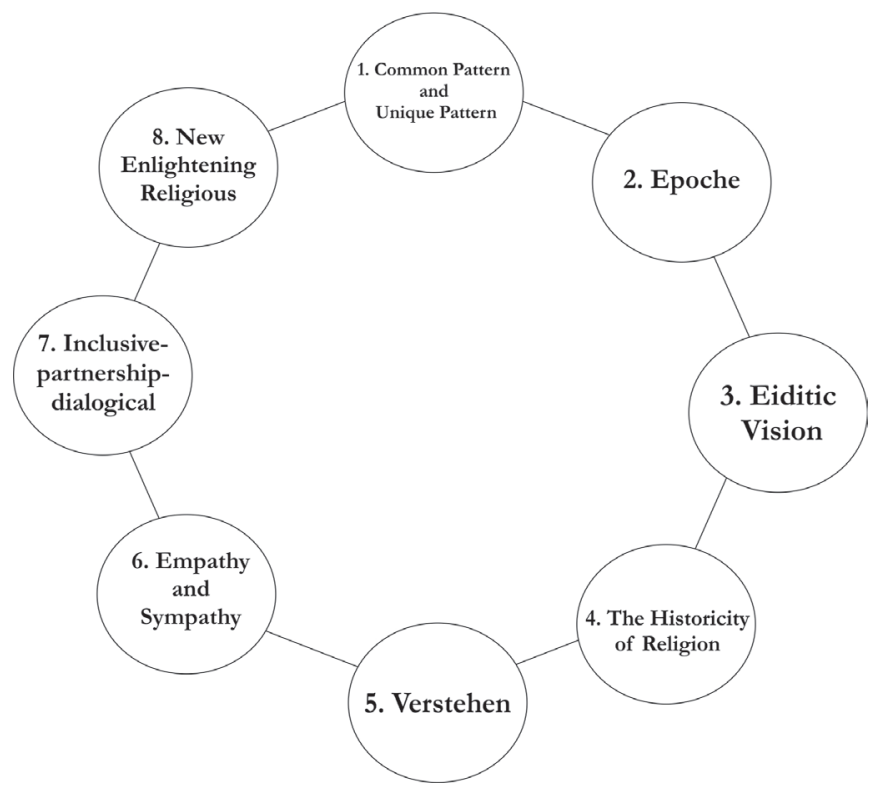

Figure 3. The fundamental features of Intersubjective type of religiousity

\section{E. Concluding Remarks}

The theoretical framework and the methodology of human sciences in religious field of studies have been examined and exposed. It is my basic assumption that progressive Muslim perspectives, from the historical point of view, can be classified into three periods as Jasser Auda has classified: the Traditionalist, the Modernist and the Postmodernist. ${ }^{44}$

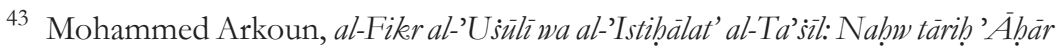
li-al-Fiker al-'islāmī, trans. by Hāšim Ṣāliḥ (Beirut: Dār al-Sāqī, 2002), p. 329.

44 Auda, Maqasid Al-Shariah as Philosophy of Islamic Law, pp. 162-91. 
The above explanation belongs to the Postmodernist type of theoretical framework in which a multidisciplinary methods and approaches are used as a unified-comprehensive tool of analysis. Multidisciplinary method and approach basically unify, converge and intermingle three elements of discipline, i.e. the discipline of Ulüm al-din (Islamic religious sciences), social sciences and contemporary humanities in one unifed thinking entity.

The relationship between those three entities and dimensions of human religiosity, namely subjectivity ('Ulüm al-dìn), objectivity (social sciences) and intersubjectivity (humanities) cannot be considered as separated entities and not related to each other. Those three entities should positively interact each other as the integrated entities. The three dimensions simultaneously move in a circle, encounter, and touch each other and meet within the mind of religious clergies, ulama or mufti themselves. The fusion of these three religious' entities, dimensions, and types of consciousness will form a new religious world view that is conducive to the formation of synergy of religious diversity in all over the globalized world. It is not easy, because the general religious education in all over the world and in many Muslim countries in general is still on the subjective level, namely in the stage of 'Ulum al-din in its classical paradigm. This type of education has not yet been introduced and touched the objective dimension of religiosity, let alone intersubjective one. Perhaps, some persons really understand and very literate of their own religions, but unfortunately, they are very illiterate, and do not understand the others' and other groups' religiosity.

In the encounter among subjective, objective and intersubjective types of religiosity, there will appear serious dialogues (biwarar) between leaders and followers of various religions, instead of polemical, defensive and apologetic jadal (debates). There will be most sincere willingness to seek eidetic vision (the essence and substance of human religiosity) guided by a strong logical reason and deepest insight of the human heartstrings (qalb salim). Criticism on the practice and implementation of religious life is not taboo, because man and women can not entirely free from any misleading 'interpretation'. It is very possible that our religious interpretation at a certain age is right, but it is not true to the era, conditions and situations and to the time when the findings of the scientific research prove that the other fact. Rejecting the possibility of misinterpretations, the clergy would 


\section{Amin Abdullah}

be very easy to fall into authoritarianism to think and act in the name of religion and argued the support of scripture verses and claiming that it was God who commanded to do so (Speaking in God's name). Religious thinking and interpretation (al-afkearr and al-tafäsir al-diniyyah) with a range of thinking on their own subjective foundation (in the area of religions; al-adyan; al-milal in the plural form) may not be right or wrong. ${ }^{45}$ If indeed his interpretation is false, then the religious people with humility and sportivity must be willing to fix after considering transparent and accountable input, criticism and public debate. Here, the method and scientific thinking are again very necessary to test the validity of religious claims in public sphere. Only by humility, restraint (self-restraint) and critical reason as it is, the style and model of the new religiosity will be more polite, open, dialogical, inclusive, integrative, transparent, not closed, not easy prejudice. A public accountability as well as responsibility will lead to the establishment of the new civilization of life of world religions that support the realization of perpetual peace and synergy of religiosity among leaders and followers of religions. The term 'kalimah saw $\vec{a}$ (a common word) in the Qur'an ${ }^{46}$ is very inspiring and enlightening for the contemporary human sciences in our globalized society.

One of the practical demands of a new system of religious thought and mentality towards perpetual peace and synergy of religiosity is to build the skills of elite religious leaders to act as community leaders, not only as religious leaders. Generally, religious leaders can only speak fluently by using language, vacabulary, idioms favourable only for their internal community, without caring of feelings of other religious groups

${ }^{45}$ Humility of religious denomination is needed at the time of tensions among religious followers in various places in the world. The concept that religious knowledge and interpretation could be wrong-not to say misleading, needs to be underlined. "Religious knowledge, like any other form of knowledge, is human, fallible, evolving and most important... constantly in the process of exchange with other forms of knowledge", as launched by Abdul Karim Soroush in Abdol Karim Soroush, Reason, Freedom, and Democracy in Islam: Essential Writings of Abdolkarim Soroush, ed. by Mahmoud Sadri, trans. by Ahmad Sadri (Oxford: Oxford University Press, 2002). Cited by Clinton Bennett in Clinton Bennett, Muslims and Modernity (New York: Continuum International Publishing, 2005), p. 122. Soroush also launches an important statement saying that "God's revelation is infallible, but our interpretation of it is not".

${ }^{46}$ Qur'an, 3: 64. Also El-Ansary and Linnan (eds.), Muslim and Christian Understanding. 
when they are speaking and leading publicly. That is the hallmark of subjective religiosity. While religious leaders who have insight and inner consciousness that they were also as community leaders will articulate the grammar, language, vocabulary, mindset, countenance, type of greetings, and choice of words adapted to the demands of intersubjective types of religious communication.

The combination between the subjective and objective is called in this paper as an intersubjective pattern of religiosity. One of the distinctive features of intersubjective types of religiosity is the ability and sensitivity of the elite groups to the presence of other communities of which their rights to be respected and guaranteed. This is the core value of multicultural society. Within the confine of intersubjective style of leadership, the religious elite requires to always use bilingual nuanced and routinely renewed religious languages (two languages, two views of the world). Mastering the language and idioms of his own tradition and religion (subjective) and at the same time mastering, understanding the vocabulary and the world view used by the other person or groups (objective). Options and string of words spoken by the community leaders who have a bilingual nuance will create appreciation of both groups-insiders and outsiders-and therefore both of them will feel not being excluded, offended, mocked, marginalized, and discriminated. It is indeed the value of human sciences in a multicultural society that underpinned and supported by religious literacy that everybody needs to build synergy of religiosity in this new globalized world. Then, what model of education and training of leadership of any candidates of religious elite and community leaders will be selected and applied? Which strategic choices will be decided to determine the direction and type of perpetual peace and synergy of religiosity? Only religious leaders and elites, political elites, scientists, scholars and researchers in the higher educations and research centres that can formulate it by using the latest scientific studies and results of in-depth research carried by various groups who focus on interfaith dialogue studies and universities having a sensitivity of a very disturbing humanitarian issues in this modern and postmodern era. 


\section{BIBLIOGRAPHY}

Abdullah, M. Amin, Pendidikan Agama Era Multikultural-Multireligius, Jakarta: PSAP, 2005.

----, "Introductory Elaboration on the Roots of Religious Violence: The Complexity of Islamic Radicalism", in Innerer Friede und die Überwindung von Gewalt: Religiöse Traditionen aud dem Prüfstand, 1st, edition, ed. by Hans M. Barth and Christoph Elsas, Hamburg: EBVerlag, 2007.

Abou El Fadl, Khaled, The Great Theft: Wrestling Islam from the Extremists, New York: Harper Collins, 2007.

Abu-Rabi', Ibrahim M., "A Post-September 11 Critical Assessment of Modern Islamic History", in 11 September: Religious Perspectives on the Causes and Consequences, ed. by Ibrahim M. Abu-Rabi' and Ian Markham, Oxford: Oneworld, 2002.

Abu-Rabi‘, Ibrahim M. and Ian Markham (eds.), 11 September: Religious Perspectives on the Causes and Consequences, Oxford: Oneworld, 2002.

Adams, Charles J., "Islamic Religious Tradition", in The Study of the Middle East: Research and Scholarship in the Humanities and the Social Sciences, ed. by Leonard Binder, New York: John Wiley \& Sons, 1976.

Adonis, al-Thäbit wa al-Mutahawnil: Baḥth fi al-Ittibä' wa al-Ibdà' 'inda al'Arab, Beirut: Dar al-Saqi, 2002.

Ali, Abdullah Yusuf (tran.), The Holy Qur'an: Text, Translation and Commentary, Beirut: Dār al Arabia, 1989.

Antes, Peter, Armin W. Geertz, and R.R. Warne (eds.), New Approaches to the Study of Religion, vols 1 \& 2, Berlin: De Gruyter, 2008.

Arkoun, Mohammed, al-Fiker al-Ușülī wa al-Istih̄älat al-Ta'șil: Naḥw Tärīh 'Ākhar li'l-Fiker al-Islāmī, trans. by Hāshim Șāliḥ, Beirut: Dār al-Sāqī, 2002.

----, "Logocentrism and Religious Truth in Islamic Thought", in Islam: To Reform or to Subvert?, London: Saqi Books, 2006.

----, Islam: To Reform or to Subvert?, London: Saqi Books, 2006.

Auda, Jasser, Maqasid Al-Shariah as Philosophy of Islamic Law: A Systems Approach, London: International Institute of Islamic Thought, 2008. 
Ba'darānī, Ihsān Tawfīq, al-Thābit wa-al-Mutaghayyir fì al-Sunnah wa-al-Sīrah al-Nabawìyah al-Sharifah, Damascus: al-Awā'il lil-Nashr wa-al-Tawzī', 2006.

Baderin, Mashood A., International Human Rights and Islamic Law, Oxford: Oxford University Press, 2003.

Barbour, Ian G., Issues in Science and Religion, New York: Harper Torchbooks, 1966.

Bennett, Clinton, Muslims and Modernity, New York: Continuum International Publishing, 2005.

Boeve, Lieven, "The Particularity of Religious Truth Claims. How to Deal with It in a So-called Postmodern Context", in Truth: Interdisciplinary Dialogues in a Pluralistic Age, ed. by Christine Helmer, Kristin De Troyer, and Katie Goetz, Leuven: Peeters, 2003.

Bowker, John (ed.), The Oxford Dictionary of World Religions, Oxford: Oxford University Press, 1997.

Cox, James L., A Guide to the Phenomenology of Religion: Key Figures, Formative Influences and Subsequent Debates, London: T \& T Clark International, 2006.

El-Ansary, Waleed and David K. Linnan (eds.), Muslim and Christian Understanding: Theory and Application of "A Common Word", New York: Palgrave Macmillan, 2010.

Ess, Josep van, "The Logical Structure of Islamic Theology", in An Anthology of Islamic Studies, ed. by Issa J. Boullata, Montreal: McGill Indonesia IAIN Development Proyect, 1992.

Guessoum, Nidhal, Islam's Quantum Question: Reconciling Muslim Tradition and Modern Science, London: I.B. Tauris, 2010.

Haddad, Yvonne Yazbeck (ed.), Muslims in the West: From Sojourners to Citizens, Oxford: Oxford University Press, 2002.

Hinnells, John R. (ed.), The Routledge Companion to the Study of Religion, London \& New York: Routledge, 2011.

Husain, Ed, The Islamist: Why I Joined Radical Islam in Britain, What I Saw inside and Why I Left, London: Oneworld Publications, 2007.

Id, Abdulrazzaq, Sadanah Hayakil al-Wahm: Naqd al-Aql al-Fiqhi (Al-Buti Namudhajan), Beirut: Dār al-'Tali'ah, 2003. 
Kant, Immanuel, Perpetual Peace, trans. by Lewis White Beck, Indianapolis: Bobbs-Merrill, 1957.

----, Religion within the Limits of Reason Alone, trans. by Theodore M. Greene and Hoyt H. Hudson, New York: Harper \& Brothers, 1960.

----, Critique of Practical Reason, trans. by Lewis White Beck, New York: Macmillan, 1985.

Knot, Kim, "Insider/Outsider Perspectives", in The Routledge Companion to the Study of Religion, ed. by John Hinnells, London and New York: Routledge, 2005.

Kung, Hans, Christianity and the World Religions: Paths to Dialogue With Islam, Hinduism, and Buddhism, Garden City, N.Y: Doubleday, 1986.

Kuntjara, Hadi, Kajian Kontra Terorisme dan Kebijakan: Radikalisme di Perguruan Tinggi Indonesia, no. 04, Jakarta: The Habibie Center, 2019.

Lambek, Michael (ed.), A Reader in the Anthropology of Religion, Malden, MA: Wiley-Blackwell, 2002.

Leaman, Oliver, An Introduction to Medieval Islamic Philosophy, Cambridge: Cambridge University Press, 1985.

Loewenthal, Kate M., The Psychology of Religion: A Short Introduction, Oxford: Oneworld Publications, 2004.

Martin, Richard C. (ed.), Approaches to Islam in Religious Studies, Tucson: The University of Arizona Press, 1985.

----, "Islam and Religious Studies: An Introductory Essay", in Approaches to Islam in Religious Studies, ed. by Richard C. Martin, Tucson: The University of Arizona Press, 1985.

McCutcheon, Russell T. (ed.), The Insider/Outsider Problem in the Study of Religion: A Reader, London and New York: Cassell, 1999.

McGuire, Meredith B., Religion: The Social Context, Belmont, CA: Wadsworth Thomson Learning, 2002.

Purwaningsih, Ayu, "Why is Radicalism Growing among Indonesian Students?”, Deutsche Welle, 11 Jun 2018, https:/ / www.dw.com/en/whyis-radicalism-growing-among-indonesian-students/a-44159778, accessed 13 Oct 2018.

Roberts, Keith A., Religion in Sociological Perspective, Belmont, CA: 
Wadsworth Publishing Company, 1995.

Saeed, Abdullah, Islamic Thought: An Introduction, New York: Routledge, 2006.

Smart, Ninian, Dimensions of the Sacred: An Anatomy of the World's Beliefs, London: Fontana Press, 1996.

----, "The Global Future of Religion", in Global Religions: An Introduction, ed. by Mark Juergensmeyer, Oxford: Oxford University Press, 2003.

Smith, Wilfred Cantwell, Islam in Modern History, Bergenfield, NJ: New American Library, 1959.

Soroush, Abdolkarim, Reason, Freedom, and Democracy in Islam: Essential Writings of Abdolkarim Soroush, ed. by Mahmoud Sadri, trans. by Ahmad Sadri, Oxford: Oxford University Press, 2002.

Swenson, Donald S., Society, Spirituality, and the Sacred: A Social Scientific Introduction, Ontario: Broadview Press, 1999.

Thoyyar, Husni, “Dunia yang Semakin Tidak Toleran”, Kompas, Jakarta, 22 Nov 2011.

Tim PPIM, "Api dalam Sekam” Keberagamaan Muslim Gen-Z: Survei Nasional tentang Keberagaman di Sekolah dan Universitas di Indonesia, Jakarta: Pusat Pengkajian Islam dan Masyarakat, UIN Syarif Hidayatullah, 2018.

Walker, Paul E., "Al-Farabi on Religion and Practical Reason”, in Religion and Practical Reason: New Essays in the Comparative Philosophy of Religions, ed. by Frank E. Reynolds and David Tracy, Albany: SUNY Press, 1994. 
M. Amin Abdullah 